\title{
ANALISIS KELAYAKAN INVESTASI PEMBELIAN MESIN FILTER PRESS UNTUK PENGURANGAN LIMBAH SLUDGE
}

\author{
Muhammad Fidiandri Putra ${ }^{1}$, Ridwan Usman $^{2}$, Rimsa Rusmiland $^{3}$ \\ Teknik Industri, Universitas Indraprasta PGRI ${ }^{1,2,3}$ \\ fidiandri.putra@gmail.com ${ }^{1}$,rrfj60@gmail.com ${ }^{2}$, ridwansmn@gmail.com ${ }^{3}$
}

\begin{abstract}
Abstrak
PT. Mustika Ratu, Tbk merupakan produsen pembuatan produk kosmetik dan jamu tradisional di Indonesia yang telah berdiri sejak tahun 1981. Total Produksi pada tahun 2016 sebesar 26.330.695 unit. Dalam keberlangsungan proses produksi tersebut perusahaan melakukan kegiatan pencucian mesin produksi setelah selesai proses, dimana air dari hasil pencucian mesin tersebut dialirkan ke Instalasi Pengolahan Air Limbah (IPAL) setiap hari sebanyak 17-34 m3. Pada proses bak kimia atau proses penjernihan air dan kenormalan $\mathrm{pH}$ (6 s/d 9) dengan penambahan tawas dan kapur. Dampak dari proses penjernihan dengan kapur ini menghasilkan endapan berupa lumpur atau sludge. Selama ini proses pengeringan sludge masih menggunakan metode Drying Bed,yaitu menggunakan pengeringan dengan pasir, koral dan ijuk. Kelemahan metode ini adalah hanya mengandalkan panas matahari, apabila musim hujan tiba bisa membuat proses pengeringan memerlukan waktu yang lebih lama. Oleh karena itu diperlukan suatu pemikiran untuk melakukan pembelian mesin filter press untuk mempercepat proses waktu pengeringan dan mengurangi jumlah volume sludge. Volume limbah sludge yang dihasilkan setiap bulan rata-rata sebanyak 8 ton per bulan dengan biaya pemusnahan \pm sebesar Rp. 6.000.000,- apabila diakumulasikan selama 1 (satu) tahun sebesar Rp. 8.400.000,-. Metode penelitian yang digunakan adalah dengan Metode Payback Periode, Net Present Value dan Profitability Index. Hasil penelitiannya dengan Nilai Investasi Pembelian Mesin Filter Press sebesar Rp. 170.000.000,- bunga 13\%/tahun, nilai present value per tahun Rp. 93.600.000,- diperoleh payback periode selama 22 bulan (1,83 tahun), nilai NPV sebesar Rp. 897.593.492,- dan nilai Profitability Index (PI) sebesar 6,3. Maka disimpulkan proyek pembelian mesin ini adalah layak.
\end{abstract}

Kata Kunci : Investasi, Pembelian, Kelayakan

\begin{abstract}
PT. Mustika Ratu, Tbk, established since 1981, is anIndonesian manufacturer of cosmetic products and traditional herbal medicines. Total Production in 2016 amounted to 26,330,695 units. In the production process, the company washes the production machine after completion of the process, during which the water as much as 17-34 $\mathrm{m} 3$ from the washing is daily discharged to the Wastewater Treatment Plant (WWTP). In a chemical vessel process or water purification process, the normal $\mathrm{pH}$ (6 to 9) can be made by adding alum and lime. This lime cleansing process produces a sludge or sludge precipitation. So far, the process of drying sludge still uses method of Drying Bed which dothe drying using sand, coral and fiber. The weakness of this method is it relies solely on the heat of the sun and the drying process takes a longer time during the rainy season. It is therefore necessary to think of purchasing a press filter machine to speed up the drying time and reduce the amount of sludge volume. Sludge waste volume monthly generated is as many as 8 tonon average, with the cost of removal of $+R p$. 6,000,000. - if accumulated for 1 (one) year, it becomes Rp. 8,400,000. -. The research methods used are Payback Period Method, Net Present Value and Profitability Index Methods. The results of his research show that with Investment Value of the Purchase of Filter Press Machine of Rp. 170,000,000. - interest of 13\% / year, present value of Rp. 93.600.000, a year - the company obtainsa payback period for 22 months (1.83 years), the value of NPV of Rp. 897,593,492. and the value of Profitability Index (PI) of 6.3. So, it is concluded that the purchase of this machine is feasible.
\end{abstract}

Keywords : Investment, purchase, feasibility 


\section{PENDAHULUAN}

PT. Mustika Ratu, Tbk merupakan produsen pembuatan produk kosmetik dan jamu tradisional di Indonesia yang telah berdiri sejak tahun 1981.Perusahaan membagi 3 (tiga) group bisnis untuk proses produksi yaitu; kosmetik cair, kosmetik padat dan jamu.Salah satu produk yang dihasilkan adalah bedak, lisptik, masker, minyak zaitun, body splash cologne, shampoo, roll on dan lainnya denganTotal Produksi pada tahun 2016 sebesar 26.330.695 unit.

Dalam keberlangsungan proses produksi tersebut perusahaan melakukan kegiatan pencucian mesin produksi setelah selesai proses, dimana air dari hasil pencucian mesin tersebut dialirkan ke Instalasi Pengolahan Air Limbah (IPAL) setiap hari sebanyak 17-34 m3. Pada proses bak kimia atau proses penjernihan air dan kenormalan $\mathrm{pH}$ (6 s/d 9)dengan penambahan tawas dan kapur. Dampak dari proses penjernihan dengan kapur ini menghasilkan endapan berupa lumpur atau sludge.

Selama ini proses pengeringan sludge masih menggunakan metode Drying Bed yaitu, menggunakan pengeringan dengan pasir, koral dan ijuk. Kelemahan metode ini adalah hanya mengandalkan panas matahari, apabila musim hujan tiba bisa membuat proses pengeringan memerlukan waktu yang lebih lama. Oleh karena itu diperlukan suatu pemikiran untuk melakukan pembelian mesin filter press untuk mempercepat proses waktu pengeringan dan mengurangi jumlah volume sludge dan periode waktu pembuangan ke PPLi (Prasadha Pamunah Limbah Industri).

Volume limbah sludge yang dihasilkan setiap bulan rata-rata sebanyak 8 ton per bulan dengan biaya pemusnahan \pm sebesar Rp. 6.000.000,- apabila diakumulasikan selama 1 (satu) tahun sebesar Rp. 8.400.000,- dan apabila diakumulasikan selama 10 tahun sebesar Rp. 84.000.000,-.
Sedangkan dari 8 ton yang dibuang ke PPLi 30-40\% nya masih mengandung air.

Studi kelayakan bisnis merupakan penelitian terhadap rencana bisnis yang tidak hanya menganalisis layak atau tidak layak bisnis dibangun, tetapi juga pada saat dioperasionalkan secara rutin dalam rangka pencapaian keuntungan yang maksimal untuk waktu yang tidak ditentukan [1],[2]. Investasi pada hakekatnya merupakan penempatan sejumlah dana pada saat ini dengan harapan untuk memperoleh keuntungan dimasa yang akan datang [3]. Investasi dibagi menjadi dua jenis [4], yaitu:

\section{Investasi nyata (real investment)}

Investasi nyata atau real investment merupakan investasi yang dibuat dalam harta tetap (fixed asset) seperti tanah, bangunan, peralatan, atau mesin-mesin.

\section{Investasi finansial (financial investment)}

Investasi finansial atau financial investment merupakan investasi dalam bentuk kontrak kerja, pembelian sahma atau obligasi atau surat berharga lainnya seperti sertifikat deposito.

Analisis Capital budgeting seringkali digunakan untuk memecahkan masalah yang dihadapi oleh manajemen, yaitu menemukan atau menciptakan proyek investasi yang menghasilkan nilai lebih tinggi dari pada biaya yang dikelurakna. Keputusan investasi yang dilakukan dengan perhitungan capital budgeting melibatkan dana yang besar dan periode waktu yang panjang. Capital budgeting melibatkan alokasi dana atas waktu yang bertujuan untuk memaksimalkan market valuedari common stock perusahaan, atau dengan kata lain adalah meningkatkan kesejahteraan pemegang saham [5].

Pemegang saham hanya tertarik dengan berapa besar pendapatan yang akan mereka terima di masa mendatang dibandingkan nilai investasi saat ini. Sehingga 
dibutuhkan incremental cash flowsatas proyek yang relative terhadap nilai investasi. Dalam perhitungan incremental cash flows maka diperlukan perhatian terhadap nilai investasi, operating cash flows, dan terminal value [5].

Salah satu keputusan penting manajemen adalah mengambil keputusan investasi dari sekian alternative yang tersedia. Terdapat berbagai prosedur evaluasi yang berbeda yang dapat digunakan manajer dalam menganalisa proyek yang potensial, yaitu adalah net present value, internal rate of return, profitability index, dan discounted payback periode [5].

Oleh karena itu diperlukan studi kelayakan investasi untuk menilai benefit/keuntungan dari pembelian mesin filter press ini dengan mengetahui berapa biaya dan waktu pengembalian investasinya dengan metode Net Present Value (NPV) dan Profitability Index (PI).

\section{METODE PENELITIAN}

Secara rinci metode peneltian yang akan digunakan meliputi ; Objek Penelitian, Jenis dan Teknik Pengumpulan Data dan Metode Analisis Data.

\section{A. Objek Penelitian}

Objek penelitian ini adalah PT. Mustika Ratu, Tbk, merupakan perusahaan yang bergerak di bidang Kosmetika dan Jamu Tradisional dimana dalam pengelolaan limbah cair melalui Instalasi Pengolahan Air Limbah (IPAL) menghasilkan sludge/lumpur dari proses kimia dengan tawas, kuriflok dan kapur.

\section{B. Jenis dan Teknik Pengumpulan Data}

Adapun jenis dan teknik pengumpulan data dalam penelitian ini adalah data kuantitatif berupa data perkiraan cashflow alternatif penggantian komponen rusak dan data perkiraan cashflow alternatif pembelian mesin filter press baru dalam 10 tahun dengan tingkat bunga $13 \%$.

\section{Metode Analisis Data}

Adapun metode analisis data menggunakan alat analisis kelayakan investasi, yaitu :

\section{Metode PP (Payback Period)}

Payback Period (PP) adalah jumlah tahun yang dibutuhkan untuk menutupi pengeluaran awal. Dengan kata lain, metode ini merupakan rasio antara initial cash investment dengan cash inflow nya dan hasilnya ditetapkan dalam satuan waktu [6]. Rumus yang digunakan :

$$
\mathrm{PP}=\frac{\text { Nilai Investasi }}{\text { Kas Masuk Bersih }} \quad \mathrm{X} 1
$$

Adapun kriteria dari penilaian dengan metode ini adalah bahwa jika payback periode lebih pendek daripada maximum payback period nya maka proyek investasi tersebut layak untuk dijalankan.Metode ini cukup sederhana untuk digunakan oleh karenanya masih terdapat kelemahan dalam menggunakan metode ini.Kelemahan utamanya adalah metode ini tidak memperhatikan konsep nilai waktu uang dan juga tidak memperhatikan aliran kas masuk setelah payback.

Metode Payback Period (PP) merupakan teknik penilaian terhadap jangka waktu (periode) pengembalian investasi suatu proyek atau usaha. Jumlah investasi x 12 bulan = Payback Period $=$ Aliran Kas Bersih. Kriteria penilaian pada payback period adalah :

a. Jika Payback period-nya < waktu maksimum, maka usulan proyek tersebut dapat diterima.

b. Jika Payback period-nya > waktu maksimum, maka usulan proyek tersebut ditolak.

\section{Metode NPV (Net Present Value)}

Net Present Value (NPV) dapat didefinisikan sebagai nilai sekarang dari cash flows di masa mendatang, di diskonto 
dengan cost of capital yang sesuai, lalu dikurangi pengeluaran awal proyek. Proyek dengan NPV positif akan diterima, dan proyek dengan NPV negative akan ditolak. Jika dua proyek mutually exclusive, NPV yang lebih tinggi yang akan diterima. Metode ini melakukan perhitungan dari cashflows dan time value of money.Rumus NPV adalah sebagai berikut [5].

$$
\mathrm{NPV}=-I_{0}+\sum_{t=n}^{n=1} \frac{C F_{t}}{(1+r)^{t}}
$$

Dimianla .

$\mathrm{CFt}=$ aliran kas per tahun pada periode $\mathrm{t}$

$\mathrm{R}$ = suku bunga / discount rate (cost of capital)

Io $=$ Investasi awal pada tahun 0

$\mathrm{t}=$ periode

$\mathrm{n} \quad=$ jumlah periode

Metode NPV merupakan metode analisis keuangan yang memperhatikan adanya perubahan nilai uang karena faktor waktu; proyeksi arus kas dapat dinilai sekarang (periode awal investasi) melalui pemotongan nilai dengan faktor pengurang yang dikaitkan dengan biaya modal (persentase bunga).

NPV = Total PV Aliran Kas Bersih - Total PV Investasi

Kriteria penilaian NPV adalah :

a. Jika NPV $>0$, maka investasi diterima.

b. Jika NPV < 0, maka investasi ditolak.

\section{Metode PI (Profitabilitas Indeks)}

PI atau cost benefit ratiodari sebuah proyek adalah cash flows dimasa mendatang dibagi dengan initial cash investment. Untuk proyek yang mutually exclusive, konflik antara PI dan NPV harus kembali mengacu kepada metode NPV.

Perusahaan terkadang tidak memiliki cukup dana untuk menghasilkan proyek yang memiliki NPV positif, akan tetapi PI dapat menghasilkan investasi yang superior [5]. Rumus dari PI adalah sebagai berikut ;

$$
\mathbf{P I}=\frac{\sum_{t=n}^{n=1} \frac{C F_{t}}{(1+k)^{x}}}{I O}
$$

Dimana :

$\mathrm{CFt}=$ cash flows dalam jangka waktu proyek

$\mathrm{k}=$ = the appropriate discount rate

Io = the initial cash outlay

$\mathrm{n} \quad=$ the projects expected life

PI= profitability index

Indeks profitabilitas adalah rasio atau antara jumlah nilai sekarang arus kas selama umur ekonomisnya dan pengeluaran awal proyek.

Total PV Kas Bersih

PI = Total Investasi

Kriteria untuk Profitabilitas Indeks :

a. Proyek dinilai layak jika PI $\geq 1,00$ sebaliknya

b. Proyek dinilai tidak layak jika $\mathrm{Pi}<1,00$

\section{HASIL DAN PEMBAHASAN}

\section{A. Proses Pengolahan Air Limbah}

Proses awal dari Bak Greasetrap (inlet) yang menampung dari air pencucian produksi kosmetik cair, ekstraksi jamu, laboratorium, toilet dan kantin. Kemudian ditransfer ke bak kimia untuk dilakukan penjernihan dan pengendapan sludge/lumpur. Air yang sudah jernih sesuai baku mutu pH, COD dan TSS ditransfer ke bak biologi (aerasi) dengan penambahan bakteri untuk mengurai limbah, lalu kemudian air dari bak biologi ditransfer ke bak clarifier untuk dilakukan mixingdan selanjutnya dilakukan tahapan terakhir dengan proses filterisasi menggunakan media sand dan carbon filter sesuai gambar lihat gambar 1 . 


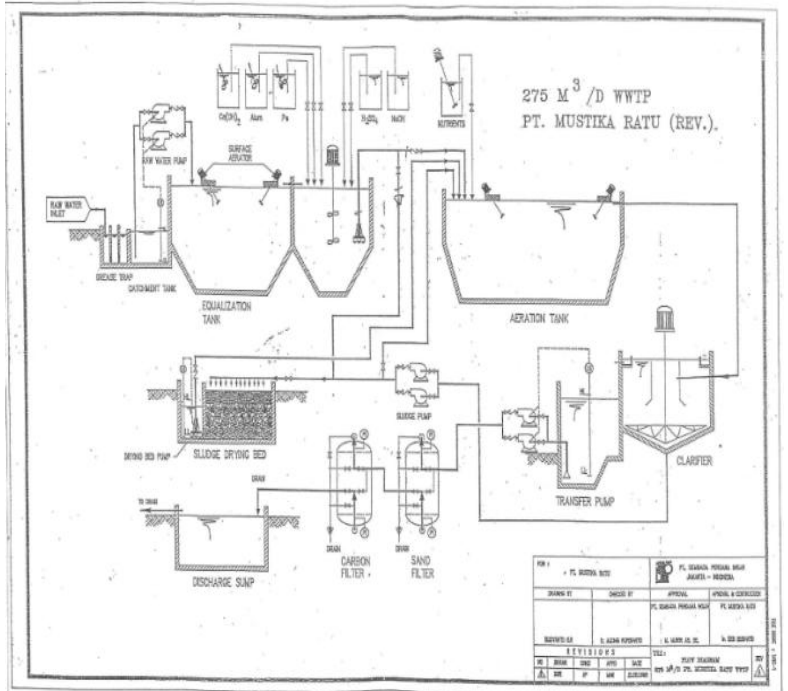

\section{Gambar 1. Flowchart Proses Pengolahan IPAL}

Selanjutnya hasil endapan dari bak kimia (Gambar 2) ditransfer ke bak Sludge Drying Bed (SDB) setelah melalui proses penambahan kapur dan tawas. Tawas untuk proses penjernihan sedangkan kapur untuk mengikat Zat Padat Terlarut (ZPT)

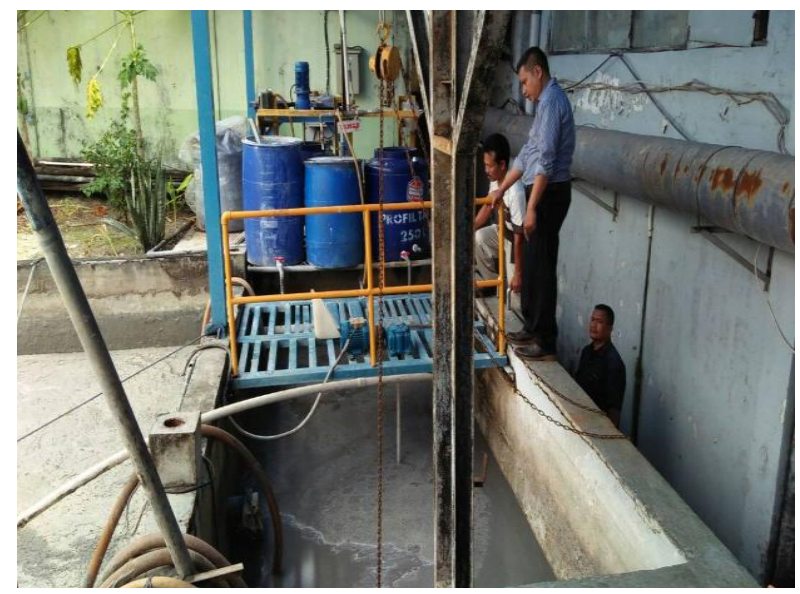

Gambar 2. Proses Penernihan Air (Bak Kimia)

Hasil dari proses pengendapan sludge ditampung untuk di filter dengan koral, pasir dan ijuk (gambar 3)dengan proses mixing melalui panel sistem (gambar 4). Panel ini berguna untuk mengontrol jumlah pemakaian kapur.

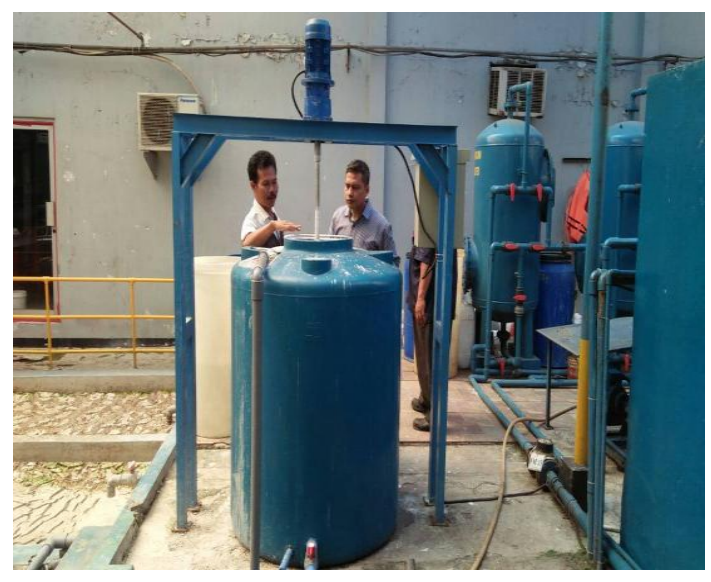

Gambar 3. Bak Sludge Drying Bed

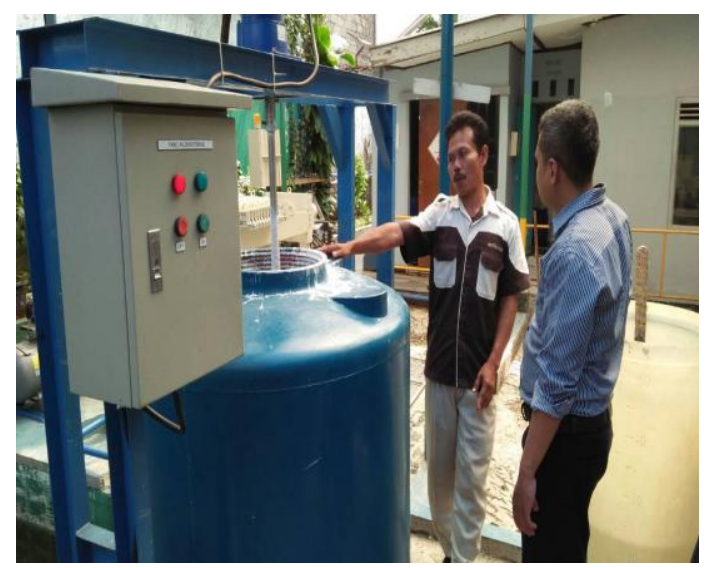

Gambar 4. Panel Mixing Sludge

B. Pembuangan Sludge (Lumpur)

PT. Mustika Ratu, Tbk dalam melakukan pengolahan limbah sludge ditampung di Tempat Penyimpanan Sementara (TPS) Limbah B3 (gambar 5) dengan titik koordinat BT-6.332904, LS 106.871864

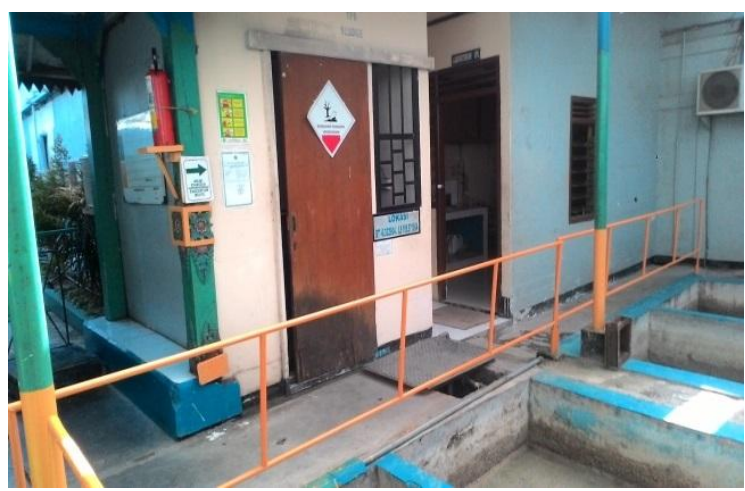

Gambar 5.TPS Sludge 
Bangunan TPS harus memiliki ijin dari Dinas Lingkungan Hidup berlaku untuk 3 (tiga) tahun.Perusahaan telah memiliki Ijin TPS Limbah B3 (gambar 6).

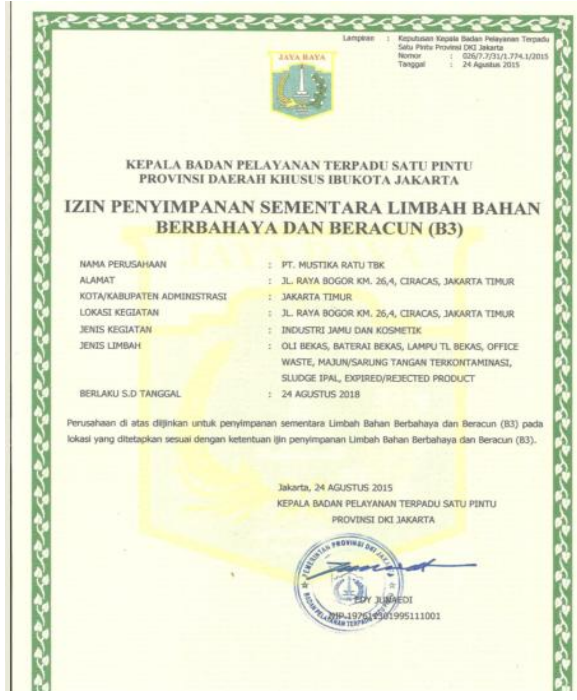

Gambar 6. Izin TPS Sludge

Debit air limbah yang dibuang ke badan sungai cipinang melalui Instalasi Pengolahan Air Limbah (IPAL) rata-rata per bulan sebesar $34 \mathrm{~m} 3 /$ hari, sedangkan ijin pembuangan air limbah dari Dinas Lingkungan Hidup Provinsi DKI Jakarta sebesar $60 \mathrm{~m} 3 /$ hari (gambar 7).

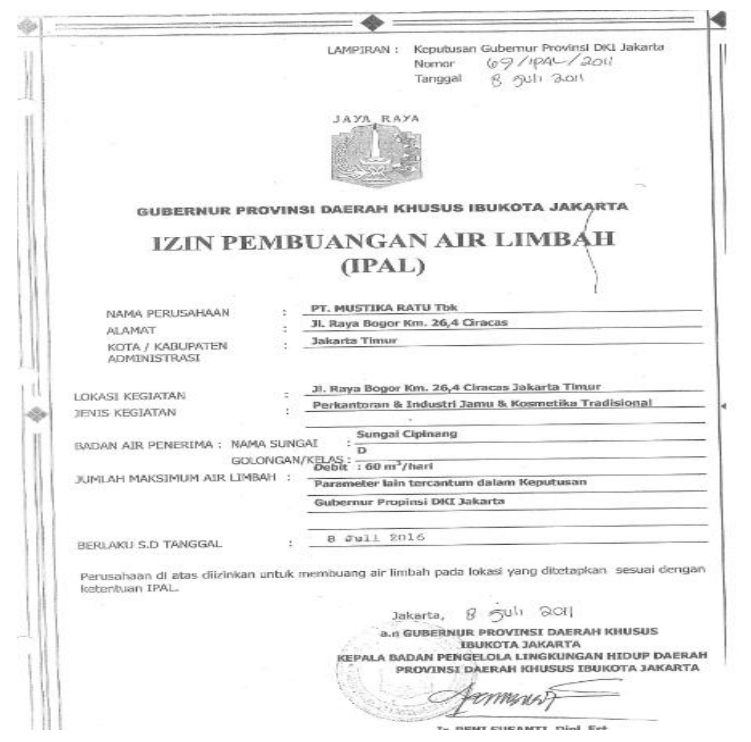

\section{Gambar 7. Izin Pembuangan Air Limbah}

Pembuangan limbah sludge dari proses kimia dengan metode SDB (Sludge Dring
Bed) kepada pihak ke-3 yang telah mempunyai izin pengolahan limbah B3 dari Kementerian Lingkungan Hidup, yaitu; Prasadha Pamunah Limbah Industri (PPLi) setiap bulan Semester II Tahun 2016 (lihat tabel 1).

\section{Tabel 1. Data Pembuangan Sludge}

\begin{tabular}{|c|c|}
\hline Bulan & Jumlah (Kg) \\
\hline Juli & 4.080 \\
\hline Agustus & 1.660 \\
\hline September & 2.240 \\
\hline Oktober & 3.820 \\
\hline November & 3.180 \\
\hline Desemebr & 4.480 \\
\hline Total & 19.460 \\
\hline
\end{tabular}

Berdasarkan tabel 1 menunjukkan jumlah pembuangan sludge sebesar 19.460 Ton dengan rata-rata per bulan sebesar 3.243 Ton.Biaya pembuangan sludge sebesar $\mathrm{Rp}$. 1.500.000/Ton, maka biaya yang dikeluarkan sebesar Rp. 4.800.000/bulan.

Dengan biaya yang begitu besar, perusahaan mulai melakukan inisiatif perhitungan apabila dilakukan pengadaan untuk pembelian mesin filter press untuk mengurangi biaya pemusnahan ke pihak ketiga.

\section{Rencana Pembelian Mesin}

Pemegang saham hanya tertarik dengan berapa besar pendapatan yang akan mereka terima di masa mendatang dibandingkan nilai investasi saat ini. Sehingga dibutuhkan incremental cash flowsatas proyek yang relative terhadap nilai investasi. Dalam perhitungan incremental cash flows maka diperlukan perhatian terhadap nilai investasi, operating cash flows, dan terminal value [5].

Proyek pembelian mesin filter press ini diharapkan bisa membantu adanya pengurangan jumlah sludge.Mesin Filter Press yang rencananya akan dibeli dengan kapasitas $60 \mathrm{~kg}$ per cycle selama 4 (empat) jam dengan debit air limbah $34 \mathrm{~m} 3$ /hari. (lihat gambar 1). Apabila 1 hari dilakukan 
4 (empat) kali proses, maka menghasilkan jumlah sludge sebanyak $240 \mathrm{~kg}$.

Limbah sludge IPAL tergolong limbah B3 berdasarkan PP No. 101 Tahun 2014 mengenai Pengelolaan Limbah B3 yang spesifik. Dengan mesin filter press diharapkan mampu mengurangi volume kadar air yang dibuang ke PPLi. Adapun gam,bar mesin filter press seperti pada gambar 5.

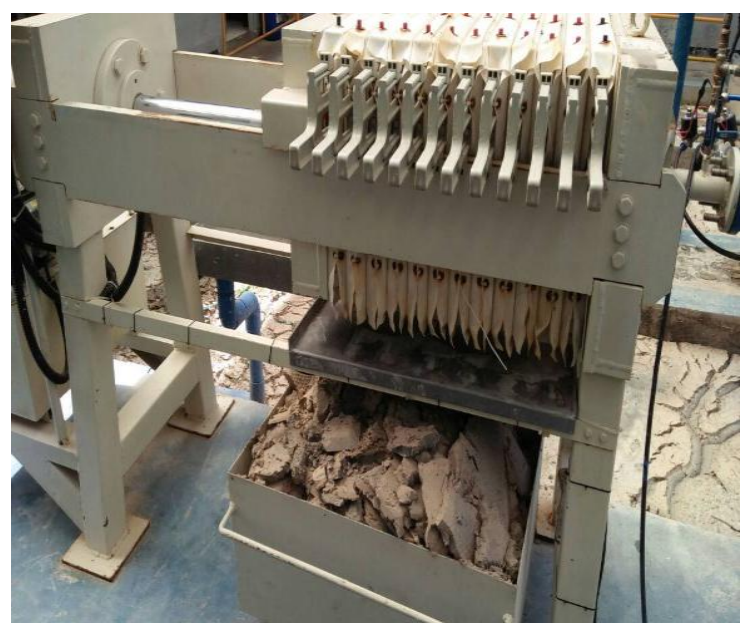

\section{Gambar 7. Contoh Mesin Filter Press}

\section{Perbandingan Biaya}

Dari hasil pengumpulan data di lapangan pada tabel 2 ditemukan bahwa dilihat dari pembandingan antara penggunaan metode drying bed dengan mesin filter press selama kurun waktu 1 (satu) tahun terdapat margin biaya operasional sebesar Rp. 93.600.000 yang menunjukkan adanya efisiensi sebesar $66,10 \%$.

Tabel 2. Perbandingan Biaya 2 (dua)

Metode

\begin{tabular}{rlcc}
\hline No. & Item Kegiatan & $\begin{array}{c}\text { Drying Bed } \\
(\text { Rp. })\end{array}$ & $\begin{array}{c}\text { MesinPress } \\
(\text { Rp. })\end{array}$ \\
\hline 1. & $\begin{array}{l}\text { Biaya } \\
\text { pembuangan } \\
\text { sludge }\end{array}$ & $72,000,000$ & $24,000,000$ \\
2. & $\begin{array}{l}\text { Pembelian pasir } \\
\text { 3. }\end{array}$ & $6,000,000$ & 0 \\
4. & $\begin{array}{l}\text { Lembur Operator } \\
\text { Lemakian }\end{array}$ & $57,600,000$ & 0 \\
& $6,000,000$ & $24,000,000$ \\
\hline & Total & $141,600,000$ & $48,000,000$ \\
\hline & Margin & $93,600,000$ \\
\hline & Sumber : Dept. UPL PT. Mustika Ratu, Tbk
\end{tabular}

Budget (anggaran) Tahun 2016 biaya pembuangan sludge ke PPLi (Tabel 3) dengan metode drying bed selama 1 (satu) tahun adalah Rp. 72.000.000 ditambah dengan biaya pembelian pasir Rp. 6.000.000, ditambah biaya lembur operator IPAL sebanyak 4 orang $x \quad R p$. 1.200.000/bulan x 12 bulan, sebesar Rp. 57.600.000 serta ditambah dengan biaya pemakaian listrik pompa sebesar Rp. 6.000.000 dengan total setahun mengeluarkan biaya Rp. 141.000 .000

\section{Tabel 3. Budget Pembuangan Sludge}

\begin{tabular}{|c|c|c|c|c|c|}
\hline \multirow{2}{*}{ No } & \multirow{2}{*}{\begin{tabular}{|l} 
URAIAN \\
PENGUJIAN EFFLUENT AIR LIMBAH BPLHD
\end{tabular}} & \multicolumn{2}{|c|}{ HARGA } & \multicolumn{2}{|c|}{ TOTAL BIAYA } \\
\hline & & $\mathrm{Rp}$ & 596,000 & $\mathrm{Rp}$ & $2,384,000$ \\
\hline 2 & BIAYA PROFESIONAL ANALISA AIR LIMBAH BPLHD & $\mathrm{Rp}$ & 500,000 & $\mathrm{Rp}$ & $2,000,000$ \\
\hline 3 & PENGUJIAN EFFLUENT AIR LIMBAH UNILAB & $\mathrm{Rp}$ & 291,000 & $\mathrm{Rp}$ & $2,328,000$ \\
\hline 4 & PENGUJIAN INFLUENT AIR LIMBAH UNILAB & $\mathrm{Rp}$ & 291,000 & $\mathrm{Rp}$ & $1,164,000$ \\
\hline 5 & PENGANGKUTAN LIMBAH PPLI & Rp & $6,000,000$ & $\mathrm{Rp}$ & $72,000,000$ \\
\hline 6 & CHEMICAL TAWAS -- $18 \mathrm{KG} \times 22 \mathrm{HARI}$ & Rp & $12,141,360$ & $\mathrm{Rp}$ & $12,141,360$ \\
\hline 7 & CHEMICAL KAPUR - - 7 KG $\times 22$ HARI & $\mathrm{Rp}$ & $5,544,000$ & $\mathrm{Rp}$ & $5,544,000$ \\
\hline 8 & KURIFLOX --- 200 GRAM X 22 HARI & $\mathrm{Rp}$ & $4,039,200$ & $\mathrm{Rp}$ & $4,039,200$ \\
\hline 9 & REAGENT & $\mathrm{Rp}$ & $5,406,000$ & $\mathrm{Rp}$ & $5,406,000$ \\
\hline 10 & KEMASAN SAMPEL & $\mathrm{Rp}$ & 500,000 & $\mathrm{Rp}$ & 500,000 \\
\hline 11 & BAKTERI ---- 4 Liter per minggu & $\mathrm{Rp}$ & $15,360,000$ & $\mathrm{Rp}$ & $15,360,000$ \\
\hline 12 & WHATMAN PAPER & $\mathrm{Rp}$ & $1,200,000$ & $\mathrm{Rp}$ & $1,200,000$ \\
\hline \multirow[t]{3}{*}{13} & EM4 & $\mathrm{Rp}$ & $3,600,000$ & $\mathrm{Rp}$ & $3,600,000$ \\
\hline & & & & $\mathrm{Rp}$ & $127,666,560$ \\
\hline & & & & $\mathrm{Rp}$ & $142,866,560$ \\
\hline
\end{tabular}

Dibandingkan dengan menggunakan mesin filter press biaya pembuangan sludge berkurang dari periodic setiap 3 (tiga) bulan menjadi Rp. 24.000.000 dan tidak memerlukan pembelian pasir dan adanya biaya lembur operator. Namun untuk pemakaian listrik dari pompa angin hidrolik 9 Bar sebesar Rp.24.000.000

\section{E. Metode Penilaian Investasi}

Pembelian mesin filter pressmempertimbangkan dengan asumsi bunga $13 \%$ dengan metode Pay back Periode, Net Present Value dan Profitability Index. Hasil perhitungannya adalah sebagai berikut: 
Tabel 4. Jumlah Kas Present Value Bersih

\begin{tabular}{cccc}
\hline Tahun & $\begin{array}{c}\text { EAIT } \\
\text { (Rp.) }\end{array}$ & $\begin{array}{c}\text { Discount } \\
\text { Factor } \\
(\mathbf{1 3 \%})\end{array}$ & $\begin{array}{c}\text { PV Kas bersih } \\
\text { (Rp.) }\end{array}$ \\
\hline 0 & 170.000 .000 & - & - \\
1 & 93.600 .000 & 0.885 & 82.831 .858 \\
2 & 93.600 .000 & 1.668 & 156.134 .388 \\
3 & 93.600000 & 2,361 & 221.003 .883 \\
4 & 93.600 .000 & 2,974 & 278.410 .516 \\
5 & 93.600 .000 & 3,517 & 329.212 .846 \\
\hline PV & 468.000 .000 & \multicolumn{3}{c}{1.067 .593 .492} \\
\hline \multicolumn{3}{c}{ Sumber : Hasil Pengolahan Data }
\end{tabular}

\section{Payback Periode (PP)}

$=\underline{\text { Rp. } 170.000 .000} \times 12$ bulan $=1,83 \mathrm{Th}$ Rp. 93.600 .000

Dilihat dari waktu pengembalian investasi selama 1,83 Tahun, apabila dibandingkan dengan waktu yang disyaratkan adalah 3 (tiga) tahun, maka proyek pembelian mesin ini sangat feasibleatau layak.

\section{Net Present Value (NPV)}

$=$ Total PV Kas Bersih - Total PV

Investasi

$=$ Rp. 1.067.593.492-Rp. 170.000.000

$=$ Rp. 897.593.492

Dilihat dari Nilai NPV yang positif, maka dengan perhitungan ini menguntungkan bagi perusahaan.

\section{Profitability Index (PI)}

$$
=\underline{\text { Total PV Kas Bersih }} \times 100 \%=6,3
$$

Total PV Investasi

Dilihat Nilai PI sebesar 6,3, maka proyek pembelian ini dinilai layak karenanilai PI $\geq 1,00$.

Pada tabel 4 hasil pengukuran penilaian kelayakan investasi dibandingkan dengan persyaratan perusahaan, maka investasi ini menguntungkan.

\section{Tabel 5. Hasil Pengukuran PP, NPV\&PI}

\begin{tabular}{clcc}
\hline No & Alat Ukur & $\begin{array}{c}\text { Hasil } \\
\text { Pengukuran }\end{array}$ & $\begin{array}{c}\text { Persyaratan } \\
\text { Perusahaan }\end{array}$ \\
\hline 1 & $\begin{array}{l}\text { Payback } \\
\text { Periode (PP) }\end{array}$ & 1,83 Tahun & 3 Tahun \\
2 & $\begin{array}{l}\text { Net Present } \\
\text { Value (NPV) } \\
\text { Profitability } \\
\text { Index (PI) }\end{array}$ & Rp. 897.593.492 & Rp. 500.000.000 \\
\hline & & Sumber : Hasil Pengolahan Data
\end{tabular}

\section{SIMPULAN}

Pembelian mesin filter press sludge sebagai pengganti mesin sludge drying bed (SBD) sangat layak dengan nilai pay back periode 1,83 tahun masih jauh dari nilai rata-rata industry sebesar 3 tahun pengembalian investasinya, Nilai Net Present Value (NPV) positif sebesar Rp. 897.593.492 dan Nilai Profitability Index sebesar 6,3. Dengan demikian proyek pembelian mesin press ini adalah layak (feasible).

Perlu dipertimbangkan faktor lainnya, seperti dalam pencatatan pemakaian listrik dengan menyediakan 1 (satu) panel khusus dan pembuatan schedule pemeliharaan mesin untuk menyediakan sparepart pendukungnya.

\section{UCAPAN TERIMAKASIH}

Penulis menghaturkan ucapan terima kasih kepada pihak terkait yaitu LPPM Universitas Indraprasta PGRI yang telah membantu dukungan finansial serta PT. Mustika Ratu, Tbk yang telah memberi kesempatan penulis untuk memberi masukan dalam penentuan proyek pembelian mesin filter press ini.

\section{DAFTAR PUSTAKA}

[1] Afandi. "Analisis Studi Kelayakan Investasi Pengembangan Usaha DistribusiPT Aneka Andalan Karya". Proceeding PESAT, Vol. 3 Oktober 2009. 
[2] Husein, Umar. Riset Pemasaran dan Perilaku Konsumen.Jakarta: PT. Gramedia Pustaka Utama.

[3] Halim, Abdul.Analisis Investasi. Edisi Kedua, Jakarta, Salemba Empat. 2005.

[4] Kasmir dan Jakfar, 2007. Studi Kelayakan Bisnis. Jakarta: Kencana. 2007.

[5] Shapiro. Modern Corporate Finance. Macmillan Publishing Company, Maxwell Macmilan International, Editor L New York. 2005.
[6] Keown,A.J., Martin, J.D., William, P., David P Scott JR. .Manajemen Keuangan : Prinsip dan Penerapan (edisi 10 jilid 1). PT. Macanan Jaya Cemerlang. 2008.

[7] Rachadian, F.M., Agassi, E.A., dan Sutopo, W. Analisis Kelayakan Investasi Penambahan Mesin Frais Baru pada CV. XYZ. Jurnal Teknik Industri Undip, Vol VIII, No.1, Januari 2013 